\title{
ANALISIS PEMBERIAN SCAFFOLDING MELALUI ONLINE FORM UNTUK MENGATASI KESULITAN BERPIKIR SPASIAL MAHASISWA
}

\author{
${ }^{1)}$ Mayang Dintarini, ${ }^{2)}$ Zukhrufurrohmah \\ 1,2 ) Program Studi Pendidikan Matematika, Universitas Muhammadiyah Malang \\ mayangdintarini@umm.ac.id
}

Received:
19/05/2021
Accepted:
04/06/2021
Published :
15/06/2021

\begin{abstract}
There are many difficulties and obstacles faced by online learning, including spatial thinking difficulties in Geometry courses. So it is necessary to provide assistance given by lecturers or researchers to overcome these difficulties. One of the efforts made is by using the Online form, which contains scaffolding. This research will describe scaffolding in overcoming students' spatial thinking difficulties through online form-based media. This research is descriptive qualitative research. The research subjects were 34 students who took online learning in the Analytical Geometry subject. The material used in this study is a circle, which is presented in an online form that is equipped with scaffolding. In the results of the study, about $21 \%$ of students had difficulty thinking spatially in working on each geometry problem, which then gave scaffolding can overcome these difficulties. On average, students can overcome their difficulties in giving second and third scaffolding.
\end{abstract}

Keywords: scaffolding, difficulties, spatial thinking, online form

\begin{abstract}
Abstrak
Banyak kesulitan dan hambatan yang dihadapi dalam pembelajaran online, termasuk di dalamnya kesulitan berpikir spasial yang muncul pada perkuliahan Geometri. Sehingga perlu adanya bantuan-bantuan yang diberikan dosen ataupun peneliti untuk mengatasi kesulitan tersebut. Salah satu usaha yang dilakukan yaitu dengan menggunakan online form yang memuat scaffolding. Pada penelitian akan dideskripsikan pemberian scaffolding dalam mengatasi kesulitan berpikir spasial mahasiswa melalui media berbasis online form. Penelitian ini berjenis kualitatif deskriptif dengan subyek sebanyak 34 mahasiswa yang mengikuti pembelajaran daring matakuliah Geometri Analitik. Materi yang digunakan adalah lingkaran, yang disajikan dalam online form yang sudah dilengkapi dengan scaffolding. Hasil analisis data menunjukkan sekitar 21\% mahasiswa mengalami kesulitan berpikir spasial dalam mengerjakan tiap soal geometri, yang kemudian dapat teratasi dengan scaffolding. Rata-rata mahasiswa dapat menjawab dengan benar soal geometri yang diberikan setelah mendapatkan scaffolding kedua dan ketiga.
\end{abstract}

Kata Kunci: scaffolding, kesulitan, berpikir spasial, online form

\section{Pendahuluan}

Era pandemi COVID-19 sepanjang tahun 2020 memaksa pembelajaran di Indonesia dilaksanakan dengan sistem online. Pembelajaran online dilaksanakan di berbagai subjek perkuliahan. Banyak kesulitan yang dihadapi guru, dosen, siswa maupun mahasiswa dalam pelaksanaannya. Mailizar, Almanthari, Maulina, \& Bruce (2020) menyatakan bahwa hambatan terbesar siswa dalam belajar ditemukan dalam pembelajaran online. Survei yang dilakukan di United States juga mengungkapkan bahwa saat ini pembelajaran online dirasa kurang efektif dibandingkan dengan pembelajaran 
tatap muka (Picciano \& Seaman, 2007). Beberapa kendala ditemukan dalam pembelajaran matematika secara online diantaranya kesulitan jaringan, banyaknya tugas, kurangnya minat belajar siswa, serta ketidakpahaman tentang apa yang dijelaskan guru. Hal serupa juga diungkapkan oleh (Handayani, 2020; Mailizar et al., 2020).

Pada jenjang sarjana program studi pendidikan matematika, matakuliah umum, pendidikan maupun matematika murni, juga dilaksanakan secara online. Seringkali kesulitan muncul pada penyampaian materi matematika murni, seperti materi geometri, aljabar, dan kalkulus. Berdasarkan wawancara awal dengan mahasiswa pendidikan matematika, matakuliah matematika murni dirasa memiliki tingkat kesulitan yang lebih tinggi dibandingkan dengan matakuliah umum dan pendidikan. Terutama matakuliah geometri. Banyak siswa beranggapan geometri merupakan materi yang sulit dipahami (Imswatama \& Muhassanah, 2016; Yohanes, Subanji, \& Sisworo, 2016). Bahkan Sutiarso \& Coesamin (2018) menyatakan bahwa geometri merupakan materi yang lebih sulit dibandingkan aljabar dan statistika.

Banyak kemampuan yang dapat terlatih dengan mempelajari geometri, khususnya berpikir spasial. Mulligan (2015) menyatakan bahwa berpikir spasial dapat ditemukan dalam permasalahan geometri seperti pengambilan perspektif, kesimetrian, ataupun objek geometri dua ataupun tiga dimensi. Penalaran spatial/kemampuan spasial/kecerdasan spasial merujuk kemampuan menyadari dan memanipulasi sifat-sifat spasial dari objek geometri dan relasi spasial antar objek. Berpikir spasial sangatlah penting untuk perkembangan matematis siswa (Barnes \& Raghubar, 2014).

Contoh penalaran spasial meliputi meletakkan, mengarahkan, menguraikan atau penyusunan ulang, keseimbangan, pendiagraman, kesimetrian, membandingkan, mengatur ukuran dan memvisualkan (Davis, 2015). Banyak mahasiswa yang menempuh matakuliah geometri mengalami kesulitan dalam berpikir spasial atau visual (Tambychik \& Meerah, 2010). Oleh karena itu, dalam belajar geometri dan dalam mengembangkan berpikir spasial mahasiswa diperlukan kerangka yang inklusif (Dindyal, 2007). Kerangka dalam penelitian ini diibaratkan sebagai sistem pembelajaran online yang dapat mengatasi kesulitan mahasiswa dalam berpikir spasial.

Online form dipilih peneliti sebagai salah satu media untuk membantu mengatasi kesulitan berpikir spasial mahasiswa dalam mempelajari geometri. Beberapa penelitian terdahulu menyatakan online form efektif untuk digunakan sebagai media pembelajaran (Batubara, 2016; Ihsan, Tiwow, \& Saleh, 2020; Radyuli, Sefriani, \& Qomariah, 2019). 
Radyuli et al., (2019) menjelaskan bahwa online form memiliki pengaruh positif terhadap hasil belajar siswa. Selain itu online form juga disenangi penggunaannya oleh mahasiswa, karena efisen, mudah diakses dan digunakan, serta hemat kertas (Batubara, 2016).

Online form yang disusun memuat video pemaparan materi mengenai lingkaran, kemudian dilanjutkan dengan latihan soal. Latihan soal telah dilengkapi scaffolding, untuk membantu kesulitan mahasiswa dalam berpikir spasial. Scaffolding merupakan istilah yang sering muncul pada teori konstruktivistik. Tepatnya scaffolding dikembangkan dari konsep Zone Proximals Developement (ZPD) yang dicetuskan oleh Vygotsky.

Scaffolding merupakan usaha mengkonstruksi kemampuan siswa yang dilakukan guru / dosen / orang dewasa. Dosen perlu mengukur level kemampuan mahasiswa, mengecek apakah ada kesulitan yang dialami, jika ada dan diperlukan dosen dapat memberikan bantuan secukupnya, hingga mahasiswa dapat mandiri (Hermkes, Mach, \& Minnameier, 2017). Penelitian lainnya juga mengatakan scaffolding efektif membantu siswa dalam meningkatkan berbagai keterampilan dan pemecahan masalah (Ismail, Ismail, \& Aun, 2015; Zurek, Torquati, \& Acar, 2014). Sutiarso \& Coesamin (2018) menyatakan scaffolding yang dimunculkn dalam beragam media cukup efektif untuk meningkatkan pemahaman konsep geometri. Berdasarkan pemaparan di atas, diperoleh tujuan penelitian ini yaitu untuk mendeskripsikan pemberian scaffolding dalam mengatasi kesulitan berpikir spasial mahasiswa melalui media berbasis online form. Tema penelitian ini berbeda dengan penelitian lain tentang scaffolding yang telah banyak diteliti. Penelitian sebelumnya pada umumnya membahas keterkaitan scaffolding dengan problem solving (Buus, 2012; Ismail, Ismail, \& Aun, 2015; Kim \& Lim, 2019). Selain itu pada penelitian sebelumnya scaffolding diberikan secara tatap muka di kelas, baik pemberiannya secara individual maupun klasikal (Wegerif \& Rojas-drummond, 2015; Zurek, Torquati, \& Acar, 2014).

\section{Metode Penelitian}

Penelitian ini merupakan penelitian kualitatif deskriptif. Subyek penelitian merupakan 34 mahasiswa yang mengikuti pembelajaran daring matakuliah Geometri Analitik. Materi yang digunakan pada penelitian ini adalah lingkaran, yang disajikan dalam online form. Online form didesain agar mahasiswa dapat belajar secara mandiri mengenai materi lingkaran. Di dalamnya terdapat video penjelasan awal mengenai 
persamaan lingkaran, kemudian mahasiswa diarahkan untuk mengerjakan 7 soal, yang sudah dilengkapi scaffolding di dalamnya. Pada setiap soal yang diberikan, disediakan scaffolding untuk membantu mahasiswa mengatasi kesulitan berpikir spasial dalam mengerjakan soal lingkaran. Scaffolding akan muncul setiap mahasiswa salah menjawab soal. Soal yang disajikan dalam online form telah divalidasi oleh 1 orang ahli yang merupakan dosen Prodi Pendidikan Matematika Universitas Muhammadiyah Malang. Proses validasi dilakukan menggunakan lembar validasi dengan menggunakan skala likert 4 level. Aspek online form yang divalidasi meliputi sistematika, kesesuaian isi dengan konsep geometri analitik, adanya soal-soal yang melatih mahasiswa untuk berpikir spasial, kesesuaian scaffolding, serta kemudahan dan keindahan tampilan. Dari hasil validasi didapatkan bahwa online form dinyatakan valid, dapat digunakan untuk mengukur kemampuan berpikir spasial mahasiswa, dan scaffolding yang diberikan telah dapat mengatasi kesulitan siswa dalam berpikir spasial.

Data scaffolding pada penelitian ini didapat dari media berbasis online form, tepatnya berasal dari rekap pada Microsoft Excel hasil pekerjaan mahasiswa. Data yang didapat kemudian di analisis scaffolding-nya menggunakan teknik analisis data kualitatif, berupa reduksi data, penyajian data kemudian penyimpulan data. Reduksi data dilakukan dengan merekapitulasi data hasil pekerjaan siswa pada online form, dengan menentukan banyaknya mahasiswa yang terbantu dengan scaffolding yang diberikan pada setiap level scaffolding. Sehingga mahasiswa dapat menyelesaikan permasalahan yang diberikan. Kemudian data hasil rekap keseluruhan disajikan dalam bentuk tabel. Kemudian peneliti mengambil 2 subyek untuk dideskripsikan perjalanan penyelesaian soalnya dengan bantuan scaffolding.

\section{Hasil dan Pembahasan}

Penelitian dilakukan secara daring, dimana dosen membuka perkuliahan melalui Learning Management System (LMS) milik Universitas Muhammadiyah yang bernama Elmu. Dosen membuka perkuliahan, dan memberikan link online form untuk dipelajari. Mahasiswa mengerjakan online form secara mandiri, tanpa adanya diskusi, maupun tanya jawab dengan dosen. Online form yang diberikan kepada mahasiswa didesain untuk dikerjakan secara individu. Berikut merupakan tampilan online form yang digunakan dalam penelitian ini. 


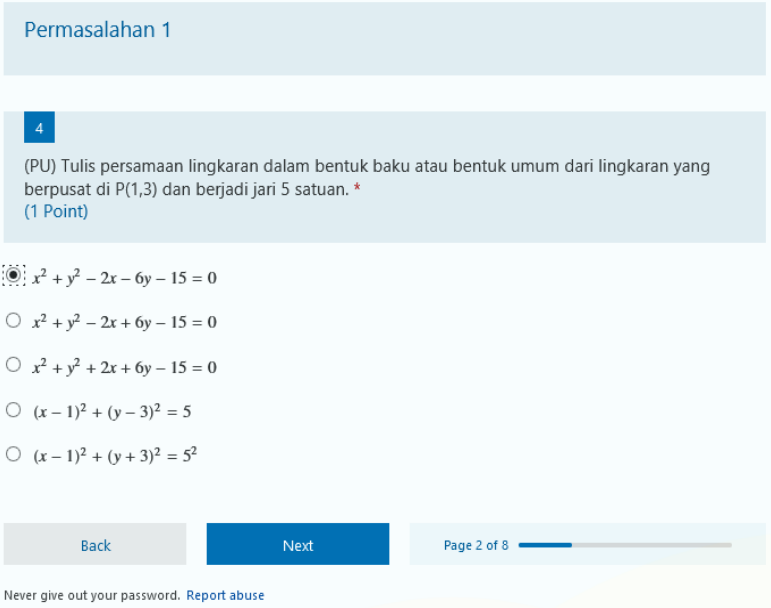

Gambar 1. Tampilan online form permasalahan 1

Gambar 1 merupakan contoh tampilan permasalahan lingkaran, mengenai bentuk persamaan lingkaran yang melalui titik tertentu serta memiliki jari-jari tertentu. Jika mahasiswa menjawab salah, maka akan muncul scaffolding pertama. Jika scaffolding pertama dijawab benar, maka mahasiswa akan diarahkan kembali pada permasalahan utama. Jika pada scaffolding pertama, mahasiswa menjawab salah, maka akan diarahkan untuk menyelesaikan scaffolding kedua. Hal ini sesuai dengan prinsip scaffolding yaitu memberikan bantuan kepada mahasiswa secukupnya dan jika diperlukan (Hermkes, Mach, \& Minnameier, 2017). Adapun hasil rekap jawaban mahasiswa pada online form adalah sebagai berikut.

\begin{tabular}{llllllll}
\multicolumn{6}{c}{ Tabel 1. Rekap Jawaban Mahasiswa pada Online form } \\
\hline Q & JB & JS & JB & JB & JB & JB & JB \\
& & & Sc-1 & Sc-2 & Sc-3 & Sc-4 & Sc-5 \\
\hline $\mathbf{1}$ & 70,6 & 29,4 & 70 & 33,3 & 0 & 0 & \\
$\mathbf{2}$ & 82,3 & 17,6 & 66,7 & 50 & 0 & 0 & \\
$\mathbf{3}$ & 82,33 & 17,6 & 100 & & & & \\
$\mathbf{4}$ & 85,3 & 14,7 & 100 & & & & \\
$\mathbf{5}$ & 73,5 & 26,5 & 77,8 & 50 & 100 & & \\
$\mathbf{6}$ & 79,4 & 20,6 & 100 & & & & \\
$\mathbf{7}$ & 76,5 & 23,5 & 12,5 & 0 & 0 & 28,6 & 60 \\
\hline
\end{tabular}

Keterangan:

Q : Question

JB : Persentase jumlah mahasiswa menjawab benar 
JS : Persentase jumlah mahasiswa menjawab benar

Sc-i : Scaffolding ke-i

$\square$ : Scaffolding tersedia, namun tidak digunakan

$\square$ : Scaffolding tidak tersedia

Pada tabel dipaparkan banyaknya jawaban benar mahasiswa pada pertanyaan utama, banyak jawaban salah pada pertanyaan utama, banyak jawaban benar pada setiap level scaffolding. Setiap soal memiliki level scaffolding berbeda. Soal $1-3$ memiliki 4 level scaffolding, soal 4 memiliki 2 level scaffolding, soal 5 memiliki 4 level scaffolding, dan soal 6-7 memiliki 5 level scaffolding. Level scaffolding dibuat berdasarkan kesukaran dan kompleksitas soal. Pada tabel 1, warna kuning menunjukkan scaffolding tersedia, namun pada aplikasi mahasiswa tidak mencapai scaffolding tersebut, untuk menyelesaikan soal yang diberikan. Warna abu-abu menunjukkan scaffolding level tersebut tidak tersedia. Dalam artikel ini, kemudian akan diideskripsikan scaffolding permasalahan 1, 2 dan 6. Hal ini dikarenakan, terdapat beberapa permasalahan yang sejenis, sehingga pembahasan secara keseluruhan permasalahan akan terkesan peneliti mengulang pembahasan yang serupa.

Pada permasalahan nomor 1, dengan soal "Tulis persamaan lingkaran dalam bentuk baku atau bentuk umum dari lingkaran yang berpusat di $\mathrm{P}(1,3)$ dan berjadi jari 5 satuan", terlihat bahwa 70,6\% mahasiswa menjawab pertanyaan utama dengan benar, sisanya 29,4\% mahasiswa menjawab salah, dan membutuhkan scaffolding untuk menjawab permasalahan. 29,4\% mahasiswa ini kemudian mendapatkan scaffolding pertama, yaitu berupa prompting dan probing, yaitu berupa pertanyaan "Pada permasalahan di atas, formula yang digunakan adalah...”. Pertanyaan ini merupakan pertanyaan pancingan untuk mengingatkan mahasiswa mengenai bentuk umum persamaan lingkaran. Ataupun berupa pertanyaan yang sifatnya menginvestigasi apakah siswa mengingat dan memahami formula bentuk umum persamaan lingkaran.

Pada scaffolding pertama, sebanyak 70\% mahasiswa yang menjawab salah pada permasalahan utama, menjawab benar, dan dapat melanjutkan menjawab permasalahan utama. Sisanya sebanyak $30 \%$ melanjutkan menjawab scaffolding kedua berupa pertanyaan yang sama persis dengan scaffolding 1. Gunanya untuk menguatkan mahasiswa mengenai bentuk umum persamaan lingkaran. Pada scaffolding kedua ini, hanya $33 \%$ mahasiswa yang menjawab benar, sedang sisanya diberi scaffolding ketiga. 
Bentuk prompting dan probing merupakan bentuk scaffolding yang lazim digunakan untuk membantu mengatasi kesulitan mahasiswa. Hal ini juga dikuatkan oleh Ryan dkk (2016) dalam penelitiannya bahwa media prompting dapat mengatasi kesulitan dalam belajar, ditandai dengan 8 dari 9 subyek penelitian sukses. Guce (2017) menyatakan bahwa prompting dapat membantu mahasiswa untuk menghubungkan matematika dengan kehidupan sehari-hari dan meningkatkan pemahaman terhadap subjek matematika itu sendiri.

Berikut merupakan tampilan scaffolding 1.

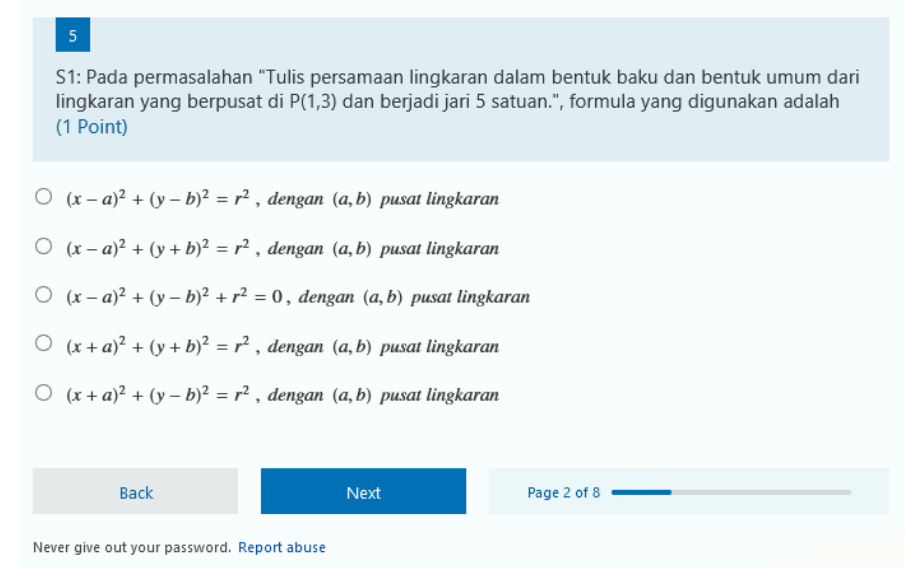

Gambar 2. Tampilan scaffolding 1 pada permasalahan 1

Scaffolding ketiga dan keempat memancing mahasiswa untuk menggunakan rumus umum persamaan lingkaran, disesuaikan dengan konteks permasalahan yang diberikan. Pertanyaan yang diberikan berupa "dengan menggunakan formula pada nomor sebelumnya, infomasi dari permasalahan "Tulis persamaan lingkaran dalam bentuk baku dan bentuk umum dari lingkaran yang berpusat di $\mathrm{P}(1,3)$ dan berjadi jari 5 satuan" menjadi ...”. Pada S3 dan S4, sebanyak 2 mahasiswa belum dapat menyelesaikan permasalahan, sehingga pada tabel di atas tertulis $0 \%$ mahasiswa yang menjawab benar. Kemudian mahasiswa akan diarahkan untuk mengamati video pembelajaran mengenai persamaan lingkaran.

Berikut merupakan tampilan scaffolding 3. 


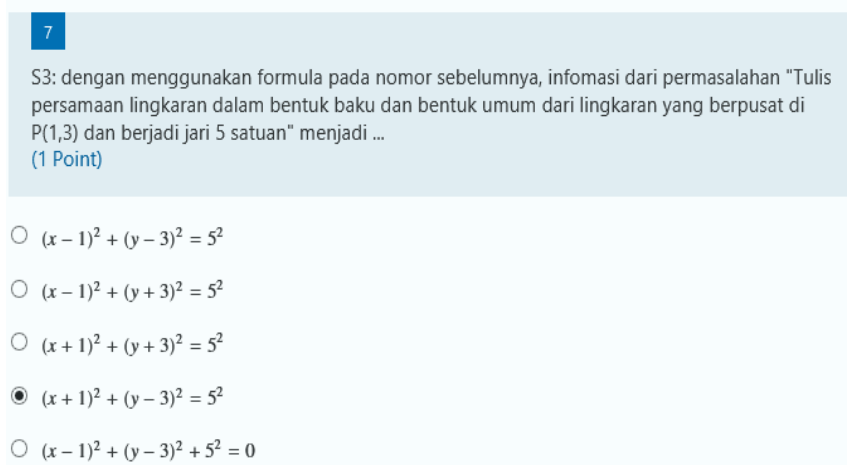

Gambar 3. Tampilan scaffolding 3 pada permasalahan 1

Permasalahan nomor 2 meminta mahasiswa untuk menentukan grafik lingkaran yang sesuai dengan persamaan yang diberikan. Berdasarkan rekap form didapati sebanyak $82,3 \%$ mahasiswa menjawab benar. Sisanya sebanyak $17,7 \%$ mahasiswa menjawab salah, dan harus mendapatkan scaffolding pertama. Scaffolding pertama berupa pertanyaan "Pusat dan jari-jari dari persamaan berikut adalah ...". Pertanyaan ini menginvestigasi kemampuan mahasiswa untuk menentukan pusat dan jari-jari lingkaran. Kemampuan yang diinvestigasi berupa kemampuan mahasiswa mengingat formula pusat dan jari-jari lingkaran, ataupun kemampuan mahasiswa memanipulasi persamaan lingkaran dalam bentuk baku menjadi bentuk umum. Dalam hal ini bentuk baku persamaan lingkaran adalah $x^{2}+y^{2}+A x+B y+C=0$, sedang bentuk umum persamaan lingkaran adalah $(x-h)^{2}+(y-k)^{2}=r^{2}$.

Scaffolding kedua diberikan pada mahasiswa yang menjawab salah pada scaffolding pertama, yaitu 50\% mahasiswa yang menjawab pada scaffolding 1. Pertanyaan yang diberikan pada scaffolding kedua, masih sama dengan scaffolding pertama, gunanya sebagai penguatan dan penggalian lebih dalam kemampuan mahasiswa. Hal ini sesuai dengan penelitian Sutiarso \& Coesamin, (2018) yang menyatakan bahwa scaffolding merupakan pendorong kuat untuk memahami konsep geometri.

Scaffolding ketiga berupa pertanyaan "Dari Gambar berikut, yang berjari-jari 5 satuan adalah ...". Pada pertanyaan scaffolding ketiga ini, sebanyak 0\% mahasiswa menjawab benar. Hal ini mengindikasikan mahasiswa masih kesulitan memvisualisasikan lingkaran dengan jari-jari $r$ pada koordinat kartesius. Sesuai dengan penelitian (Ahmad, Tarmizi, \& Nawawi, 2010), yang menyatakan bahwa visualisasi dalam berpikir spasial merupakan kesulitan terbesar yang dihadapi siswa atau mahasiswa dalam mempelajari 
matematika. pada penelitiannya, hanya $2 \%$ masalah yang dapat diselesaikan siswa menggunakan representasi visual.

Mahasiswa kemudian dibawa pada scaffolding keempat. Dengan tema yang masih sama, yaitu menentukan jari-jari lingkaran. Kali ini mahasiswa diminta melihat jari-jari lingkaran sebagai jarak dua titik yaitu titik pusat dan sebarang titik pada lingkaran. Pertanyaan scaffolding keempat yaitu "Misalkan pusat lingkaran $P\left(x_{1}, y_{1}\right)$ dan titik lain pada lingkaran $B\left(x_{2}, y_{2}\right)$. Jari-jari lingkaran $\mathrm{L}$ dapat ditemukan dengan ...". Pada scaffolding keempat ini mahasiswa yang menjawab benar juga $0 \%$.

Pada permasalahan keenam, ditampilkan gambar grafik lingkaran pada koordinat kartesius, kemudian mahasiswa diminta menentukkan persamaan lingkaran yang sesuai dengan gambar. Dalam permasalahan ini, mahasiswa harus jeli melihat bagaimana mereka bisa menetukan persamaan lingkaran, jika tidak diketahui titik pusat dan jarijarinya. Terdapat $79,4 \%$ mahasiswa menjawab benar pada pertanyaan inti ini. Sisanya sebesar 20,6\% mahasiswa menjawab salah dan perlu diberikan penguatan dengan scafolding 1. Scaffolding 1 menguatkan dan menekankan mahasiswa untuk memperhatikan tiga titik yang dilewati lingkaran. Pertanyaan scaffolding 3 yaitu "Persamaan lingkaran seperti pada gambar merupakan persamaan lingkaran yang melalui 3 titik yaitu". Dengan scaffolding 3 ini, 100\% mahasiswa dapat menjawab dengan benar. Berikut merupakan tampilan permasalahan 6.

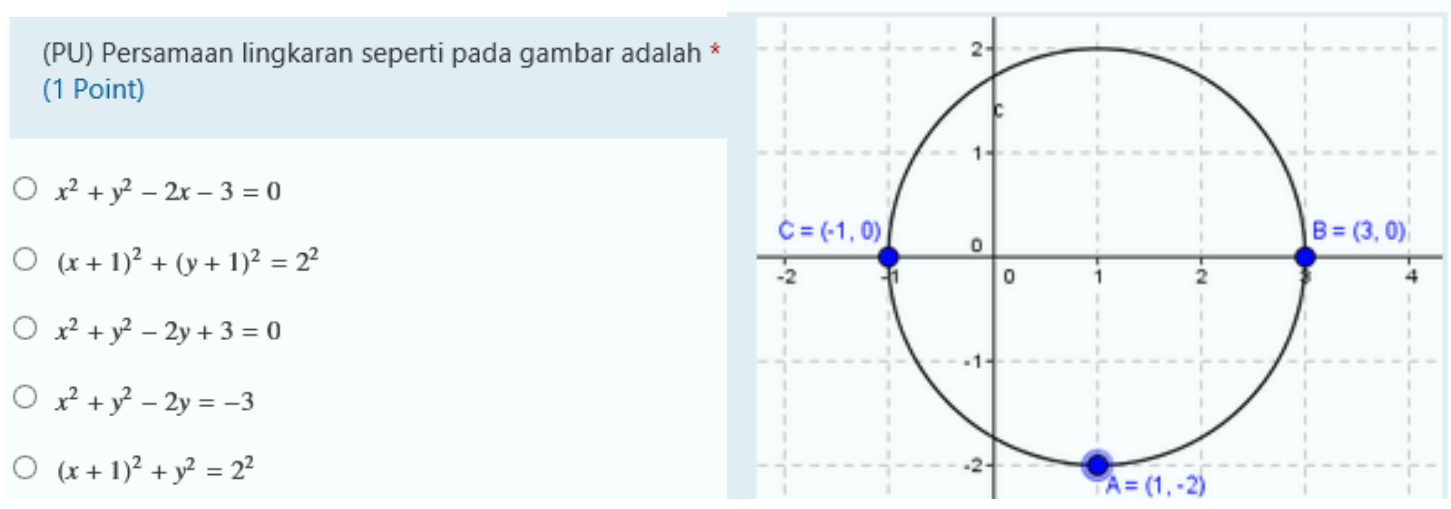

Gambar 4. Tampilan Permasalahan 6

\section{Kesimpulan dan Saran}

Pemberian scaffolding dalam online form dapat digunakan untuk mengatasi kesulitan berpikir spasial mahasiswa. Hal tersebut dideskripsikan pada hasil penelitian, bagaimana online form dapat didesain sebagai media pemberian scaffolding dalam pembelajaran online. Secara garis besar, sekitar $21 \%$ mahasiswa mengalami kesulitan 
berpikir spasial dalam mengerjakan tiap soal geometri. Hal ini dapat dilihat dari rata-rata mahasiswa yang menjawab salah pada soal nomor 1 sampai 7. Kemudian pemberian scaffolding dapat mengatasi kesulitan tersebut. Rata-rata mahasiswa dapat mengatasi kesulitannya pada pemberian scaffolding kedua dan ketiga. Walaupun masih ada mahasiswa yang tidak bisa mengatasi kesulitan berpikir spasialnya melalui pemberian scaffolding tersebut, terutama pada soal nomor 7. Hal ini dimungkinkan karena scaffolding yang diberikan kurang sesuai dengan bentuk kesulitan mahasiswa.

Pada penelitian selanjutnya diharapkan peneliti menilik lebih dalam kesulitan siswa dalam berpikir spasial, sehingga dapat dikembangkan media-media lain berbasis scaffolding yang dapat membantu mengatasi kesulitan tersebut. Penelitian selanjutnya juga perlu mengangkat tema diagnosis kesulitan dalam pembelajaran online dan solusi tepatnya untuk mengatasi kesulitan tersebut. Mengingat banyaknya permasalahan dalam pembelajaran online yang belum ditemukan solusinya.

\section{Ucapan Terima Kasih}

Terima kasih pada Universitas Muhammadiyah Malang yang telah mendanai penelitian ini, sampai dengan publikasinya.

\section{Pustaka}

Ahmad, A., Tarmizi, R. A., \& Nawawi, M. (2010). Visual Representations in Mathematical Word Problem Solving Among Form Four Students in Malacca. In Procedia - Social and Behavioral Sciences (Vol. 8, pp. 356-361). Malacca: Elsevier Ltd. https://doi.org/10.1016/j.sbspro.2010.12.050

Barnes, M. A., \& Raghubar, K. P. (2014). The British Childhood Cancer Survivor Study: Objectives, methods, population structure, response rates and initial descriptive information. Pediatric Blood \& Cancer, 61(10), 1729-1733. https://doi.org/10.1002/pbc

Batubara, H. H. (2016). Penggunaan Google Form Sebagai Alat Penilaian Kinerja Dosen di PRODI PGMI UNISKA Muhammad Arsyad Al Banjari. AL-BIDAYAH, 8(2), 39-50.

Davis, B. (2015). Spatial Learning In The Early Years: Principles, Assertions, and Speculations. New York: Routledge.

Dindyal, J. (2007). The Need for an Inclusive Framework for Students' Thinking in School Geometry. Montana Council of Teachers of Mathematics, 4(11), 15513440 .

Guce, I. K. (2017). Investigating College Students ' Views on Mathematics Learning Through Reflective Journal Writing. International Journal of Evaluation and Research in Education, 6(1), 38-44. 
Handayani, L. (2020). Keuntungan, Kendala dan Solusi Pembelajaran Online Selama Pandemi Covid-19: Studi Ekploratif di SMPN 3 Bae Kudus Lina Handayani. Journal Industrial Engineering \& Management Research, 1(2), 15-23.

Hermkes, R., Mach, H., \& Minnameier, G. (2017). Interaction-based coding of scaffolding processes. Learning and Instruction, 54, 147-155. https://doi.org/10.1016/j.learninstruc.2017.09.003

Ihsan, N., Tiwow, V. A., \& Saleh, M. (2020). Pemanfaatan Aplikasi Google Form dalam Monitoring Kegiatan Kuliah pada Program Studi Fisika Universitas Negeri Makassar. In Prosiding Seminar Nasional Fisika PPs UNM (Vol. 2, pp. 21-24). Makasar.

Imswatama, A., \& Muhassanah, N. (2016). Analisis Kesalahan Mahasiswa dalam Menyelesaikan Soal Geometri Analitik Bidang Materi Garis dan Lingkaran. Suska Journal of Mathematics Education, 2(1), 1-12.

Ismail, N., Ismail, K., \& Aun, N. S. M. (2015). The Role of Scaffolding in Problem Solving Skills among Children. In International Proceedings of Econemics Development and Resesearch (Vol. 85, pp. 154-158). Singapore: IACSIT Press.

Mailizar, Almanthari, A., Maulina, S., \& Bruce, S. (2020). Secondary School Mathematics Teachers, Views on E-learning Implementation Barriers during the COVID-19 Pandemic : The Case of Indonesia. EURASIA Journal of Mathematics, Science and Technology Education, 16(7), 1-9.

Mulligan, J. (2015). Looking within and beyond the geometry curriculum : connecting spatial reasoning to mathematics learning. ZDM, 47(3), 511-517. https://doi.org/10.1007/s11858-015-0696-1

Picciano, A. G., \& Seaman, J. (2007). K-12 Online Learning. New York: SLOAN-C.

Radyuli, P., Sefriani, R., \& Qomariah, N. (2019). Pembelajaran Inquiry Menggunakan Google Form Terhadap Hasil Belajar Simulasi Dan Komunikasi Digital (Case study of class X of SMK Negeri 9 Padang). EDUKATIF: Jurnal Ilmu Pendidikan, 2(1), $56-63$.

Ryan O. Kellems, Kaitlyn Frandsen, Blake Hansen, Terisa Gabrielsen, Brynn Clarke, Kalee Simons, K. C. (2016). Research in Developmental Disabilities Teaching multi-step math skills to adults with disabilities via video prompting. Research in Developmental Disabilities, 58, 31-44. https://doi.org/10.1016/j.ridd.2016.08.013

Sutiarso, S., \& Coesamin, M. (2018). The Effect Of Various Media Scaffolding On Increasing Understanding Of Students ' Geometry Concepts. Journal on Mathematics Education, 9(1), 95-102.

Tambychik, T., \& Meerah, T. S. M. (2010). Students' difficulties in mathematics problem-solving: What do they say? Procedia - Social and Behavioral Sciences, 8(5), 142-151. https://doi.org/10.1016/j.sbspro.2010.12.020

Yohanes, B., Subanji, \& Sisworo. (2016). Students' Cognitive Load in Geometry Learning. Jurnal Pendidikan: Teori, Penelitian Dan Pengembangan, 1(2), 187-195.

Zurek, A., Torquati, J., \& Acar, I. (2014). Scaffolding as a Tool for Environmental Education in Early Childhood. International Journal of Early Childhood Environmental Education, 2(1), 27-57. 
